\title{
Coexistence of Fabry Disease and immune complex glomerulonephritis: report of two cases in a single family
}

\author{
Coexistência de doença de Fabry e glomerulonefrite por imunocomplexos: relato de dois \\ casos em uma única família
}

Coexistencia de enfermedad de Fabry y glomerulonefritis por complejos inmunes: reporte de dos casos en una sola família

José Tibúrcio do Monte Neto ${ }^{1}$, Nayze Lucena Sangreman Aldeman ${ }^{1}$, Roosevelt Valente Chaves ${ }^{1}$, Adalberto Socorro da Silva1 ${ }^{1}$, Ester Miranda Pereira ${ }^{1}$, Rafael Melo Santos de Serpa Brandão', Antonio Vanildo de Sousa Lima ${ }^{1}$, Daniel Santos Rocha Sobral Filho ${ }^{1}$, Semiramis Jamil Hadad do Monte $^{1 *}$.

\begin{abstract}
Objective: To describe two cases of Fabry disease (FD) from the same family nucleus associated with Membranous Nephropathy (MN) and Systemic Lupus Erythematosus (SLE). Case report: We present an index case of a 61-year-old man with nephrotic syndrome and FD (c.1046G >C p.W349S) and his daughter with systemic lupus erythematosus. Appropriate diagnosis based on renal biopsy allowed to conclude that it was, in fact, a primary membranous glomerulopathy caused by the formation of autoantibody against phospholipase $\mathrm{A} 2$ receptor and a class $\mathrm{V}$ nephritis, respectively, in the index case and his daughter, associated to glycosphingolipid inclusions in renal cells with areas of podocyte effacement. Final considerations: Although FD diagnosis be performed by biochemical and molecular tests, a detailed analysis of the kidney biopsy is essential to diagnose the coexistence of FD and autoimmune diseases, thus allowing a more adequate treatment.
\end{abstract}

Keywords: Fabry Disease, Membranous Nephropathy, Systemic Lupus Erythematosus.

\section{RESUMO}

Objetivo: Descrever dois casos de doença de Fabry (DF) de um mesmo núcleo familiar associado com Nefropatia Membranosa (NM) e Lupus Eritematoso Sistemico (LES). Detalhamento do caso: Apresentamos um caso índice de um homem de 61 anos com síndrome nefrótica e DF (c.1046G> C p.W349S) e sua filha com DF e LES. O diagnóstico apropriado baseado na biópsia renal permitiu concluir que era de fato uma glomerulopatia membranosa primária causada pela formação de autoanticorpo contra 0 receptor da fosfolipase $\mathrm{A} 2$ e uma nefrite classe $\mathrm{V}$, respectivamente, no caso índice e sua filha, associada a inclusões glicoesfingolipídeos em células renais com áreas de desorganização estrutural dos podócitos. Considerações finais: Apesar do diagnóstico da DF ser realizado por testes bioquímicos e moleculares, a análise minuciosa da biopsia renal é fundamental para diagnosticar a coexistência de DF e doenças autoimunes possibilitando, assim, um tratamento mais adequado.

Palavras-chave: Doença de Fabry, Nefropatia Membranosa, Lúpus Eritematoso Sistêmico.

${ }^{1}$ Universidade Federal do Piauí, Teresina-PI. *E-mail: semiramis@ufpi.edu.br

SUBMETIDO EM: 3/2019 ～ACEITO EM: 4/2019 ～～PUBLICADO EM: 7/2019 


\section{RESUMEN}

Objetivo: Describir dos casos de enfermedad de Fabry (EF) de un mismo núcleo familiar asociado con Nefropatía Membranosa (NM) y Lupus Eritematoso Sistemico (LES). Reporte de caso: Presentamos un caso índice de un hombre de 61 años con síndrome nefrótico y FD (c.1046G> C p.W349S) y su hija con lupus eritematoso sistémico. El diagnóstico apropiado basado en la biopsia renal permitió concluir que en realidad era una glomerulopatía membranosa primaria causada por la formación de autoanticuerpos contra el receptor de fosfolipasa $A 2$ y una nefritis de clase $V$, respectivamente, en el caso índice y su hija, asociada a inclusiones de glicosfingolípidos en células renales con áreas de borramiento de podocitos. Consideraiones finales: A pesar del diagnóstico de la EF ser realizado por pruebas bioquímicas y moleculares, el análisis minucioso de la biopsia renal es fundamental para diagnosticar la coexistencia de EF y enfermedades autoinmunes posibilitando así un tratamiento más adecuado.

Palabras clave: Enfermedad de Fabry, Nefropatía Membranosa, Lupus Eritematoso Sistémico.

\section{INTRODUCTION}

Fabry Disease (FD; OMIM:301500) is a rare X-linked lysosomal storage disorder caused by deficient activity of $\alpha$-galactosidase A enzyme ( $\alpha$-GAL A) (DESNICK RJ, et al., 2001). The reason that leads to the deficiency of the enzymatic activity is due to the existence of several mutations that occur in the GLA gene that affect the synthesis, processing, and the stability of a-GAL A (LEMANSKY P, et al., 1987).

The defective enzyme leads the progressive accumulation of glycosphingolipids, especially globotriaosylceramide (Gb3) and lyso-Gb3, in plasma and in a wide range of cell types throughout the body inducing inflammatory processes, ischemia, hypertrophy and the development of fibrosis. (MEHTA A and HUGHES DA, 2017).

The prevalence of FD is estimated to be between 0.85 and 2.5 cases per 100,000 inhabitants worldwide, however this estimate may be underestimated due to the different clinical forms preformed by Fabry disease, making it possibly an underreported disease. (MEHTA A, et al., 2004).

Depending on the a-Gal A activity, in addition to other factors, Fabry disease may present several forms of clinical manifestation, ranging from the apparently asymptomatic form observed occasionally in females to the classic severe phenotype in males (MEHTA A, et al., 2009).

Like the most lysosomal disorders, FD is a systemic disease, with a wide spectrum of clinical manifestations mainly affecting the heart, the central nervous system (CNS), and the kidneys (MEHTA A and HUGHES DA, 2017). Among clinical manifestations of FD, Fabry nephropathy (FN) is one of the most severe manifestations of FD and was the cause of death before the widespread availability of enzymatic replacement therapy (ERT). Frequently, patients with no family history of FD are first diagnosed by a nephrologist during investigation of Chronic Renal Disease (CKD) with unknown etiology through renal biopsy. Glomerular sclerosis and tubulointerstitial fibrosis are the histological features that best correlate with the progression of FN in humans (VALBUENA C, et al., 2008).

Like most aspects of FD, kidney disease is thought to result from Gb3 accumulation in glomerular endothelial, mesangial and interstitial cells, podocytes and renal vasculature. Deposition of Gb3 and lysoGb3 can promote vascular smooth muscle cell proliferation and the release of mediators of glomerular injury such as TGF- $\beta$, a critical mediator of extracellular matrix production (ECM), fibrosis and podocyte lesion (SANCHEZ-NIÑO MD, et al., 2011).

Podocyte injury is the primary factor in the progression of CKD (ICHIKAWA MA, et al., 2005) and in the FD context the Gb3 accumulation in podocytes start in early childhood (TONDEL C, et al., 2008). Podocyte injury causes shortening of the primary and secondary podocytes processes that bind it to the glomerular 
basement membrane (GBM), an effect known as podocyte effacement, leading to tearing of the podocyte that is excreted in the urine. With the initial loss of podocytes, the remaining podocytes responded by compensatory hypertrophy. However, continuous loss of podocytes is cumulative, and the remaining podocytes become unable to compensate for the lost cells, resulting in sclerosis of the entire glomerulus (KRIZ W, et al., 2013).

Other factors considered to be involved in the pathophysiology are the rupture of the lysosome (PLATT FM, et al., 2012) and damage due to local inflammation, activation of pro-apoptotic pathways and destruction of the podocytes by cytotoxic mechanisms, showing the role of the immune system in the pathophysiology of FD (MAUHIN W, et al., 2015).

Besides, Gb3 accumulation may alter the nature of cell membranes, e.g. lymphocyte cell membranes, resulting in a change in the cell surface signaling, gene regulation, and subsequent protein expression, creating an environment capable of providing autoimmune responses. This observation corroborates what is known about defects in immune cells in systemic lupus erythematosus (SLE) patients, where the composition of lipids in the lymphocyte cell membranes is altered (including Gb3) and may lead to an increase in the activation of these pathways (JURY EC, et al., 2007).

As the role of GB3 accumulation in the development of autoimmune disease has not yet been elucidated, it becomes another challenge for diagnosis, since the patient presents a hereditary disease difficult to diagnose and sometimes asymptomatic (FD), but requires attention to the manifestations of autoimmune diseases, leaving the professional the difficult task of defining whether is an association of diseases or DF only. Some cases have already been reported from patients with FD associated with other glomerular diseases, e.g., lupus nephritis, thin basement membrane nephropathy, crescentic glomerulonephritis, immunoglobulin A nephropathy, and rheumatoid arthritis-associated renal diseases (LIU Y, et al., 2016).

Here, we will describe two cases of FD of a family nucleus one associated with membranous nephropathy (MN) and another with SLE.

\section{CASE REPORT}

\section{Case 01}

A 61-year-old man arrived at the hospital in 2014 with clinical status of nephrotic syndrome. Previously, he had been diagnosed with cardiomyopathy and had been using beta-blockers continuously.

He did not report any family history of genetic diseases, diabetes mellitus, infectious diseases, and/or neoplasias. However, he had a daughter diagnosed with SLE.

The physical examination showed that the patient was normotensive and had generalized nephrotic-like edema, whereas complementary laboratory examinations for viral and neoplasia diseases were negative.

A complementary immunohistochemical study carried out in recovered kidney tissue biopsy from paraffin blocks revealed scarce deposits of anti-phospholipase A2 antibodies (anti-PLA2) and IgG4 GBM. The presence of anti-PLA2 antibodies was also confirmed in the peripheral blood, as per results (ratio of 3.84) of ELISA assays (EUROIMMUN, Lübeck, Germany).

In the kidney function evaluation and biochemical parameters, the patient exhibited nephrotic proteinuria (7g/24 hours), hypoalbuminemia (2.2g/dL), dyslipidemia, and a measured Glomerular Filtration Rate (GFR) of $72.6 \mathrm{ml} / \mathrm{min} / 1.73 \mathrm{~m}^{2}$.

Renal biopsy found: (i) Light microscopy revealed vacuolization of podocyte cells, diffuse thickening, duplication and formation of spicules in the Glomerular Basement Membrane (GBM); (ii) Immunofluorescence (IF) showed IgG, IgM, Kappa, Lambda, and C3 deposits; (iii) Electron microscopy (EM) confirmed stage 3 of membranous nephropathy and lipid deposits exclusively in podocytes, questioning whether it was FD (Figure 1). 
Figure 1 - Electron microscopy: Case 01 - (A) Presence of lipid deposits in the cytoplasm of podocytes (gray arrows). (B) Presence of subepithelial amorphous deposits, some in reabsorption (white arrows).

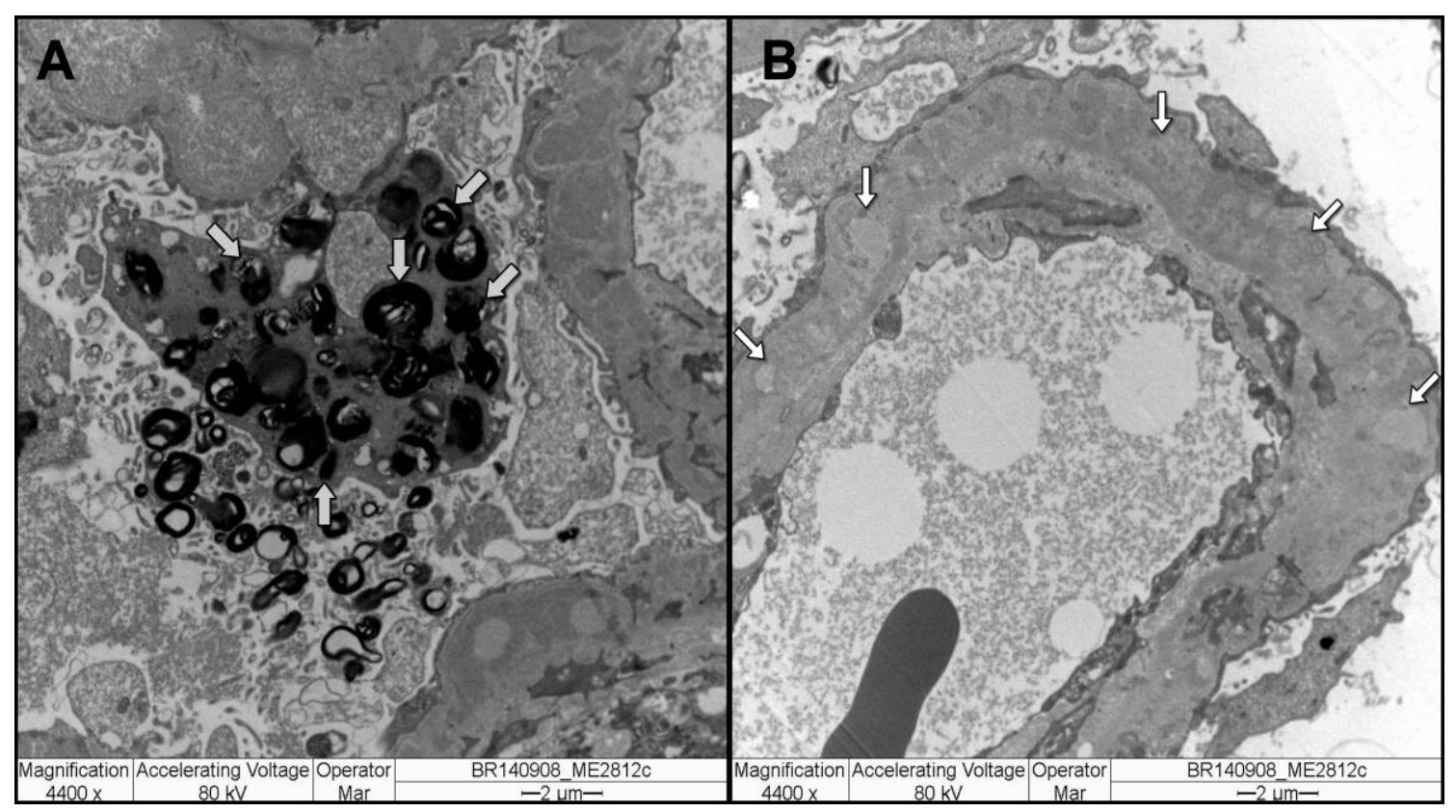

Source: Dr. Marlene Antônia dos Reis, 2019.

Given the suspicion that the patient had FD, complementary examinations were requested to help diagnosis. Table 1 shows that the patient presented accumulation of lyso-GB3, with an important reduction of the enzymatic activity of the $\alpha-G A L$ A enzyme and Fabry Disease manifestations in organs and tissues such as heart and cornea.

Table 1 - Clinical and Laboratory data of index patient.

\begin{tabular}{lcc}
\hline Clinical and Laboratory data & Index patient & Reference Values \\
\hline Lyso-Gb3 $(\mathrm{ng} / \mathrm{mL})$ & 14.6 & $<1.8$ \\
a-GAL A activity $(\mu \mathrm{mol} / \mathrm{L} /$ hour $)$ & 0.2 & $>1.9$ \\
Cornea verticillata & Yes & No \\
LV mass Index $\left(\mathrm{g} / \mathrm{m}^{2}\right)$ & 208 & $<149$ \\
\hline Lyso-Gb3: globotriaosylsphingosine; LV left ventricular. & \\
Source: The authors, 2019. & &
\end{tabular}

With laboratory and genomic findings compatible with FD associated with primary MN, the Enzyme

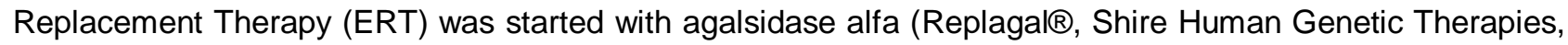
Cambridge, MA, USA) in recommended doses and intervals, associated with the blockage of the angiotensin II receptor.

The exonic and splicing regions sequencing of the GLA gene allowed the identification of a pathogenic hemizygous mutation in the exon $7 \mathrm{c} .1046 \mathrm{G}>\mathrm{C}$ p.W349S. After confirmation of the mutation in the proband and the family member's consent, a family screening to detect the mutation in the GLA gene was performed. The screening result allowed to make a pedigree with 29 individuals distributed in five generations. Except for the first generation, all the others had affected individuals in both genders, being four males and seven females (Figure 2). 
Figure 2. Genealogy of five generations of Fabry Disease (FD) carriers diagnosed from Case 01, in the state of Piauí, Brazil. The arrow indicates the family's index case. Circles = women; squares = men; gray solid symbols = family members diagnosed with FD.

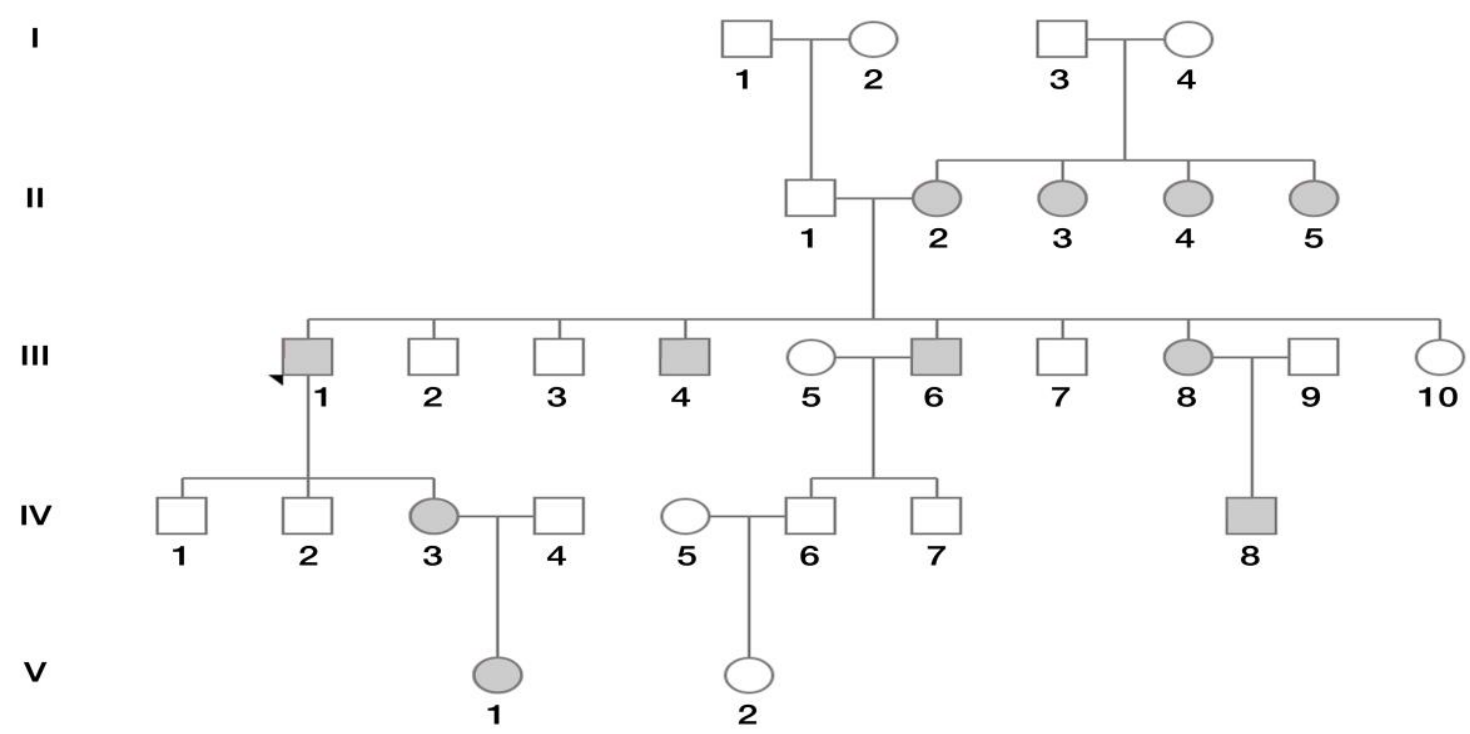

Source: The authors, 2019.

Figure 3 shows the case's evolution after the start of ERT with Replagal. An expressive and early reduction is observed of the left ventricular mass index (LVMI) (Figure 3-A); reduction of the 24h proteinuria values (Figure 3-B); and an increase of estimated Glomerular Filtration Rate (eGFR) (Figure 3-C). Although proteinuria remains at a high level $(2.4 \mathrm{~g} / 24 \mathrm{~h})$, the patient recovered plasma albumin and re-balanced the intravascular with the disappearance of the edemigenic status. The concentration of lyso-Gb3 after 24 months of ERT was $12.3 \mathrm{ng} / \mathrm{mL}$, and the cardiac magnetic resonance showed a small fibrosis area in the left ventricular corresponding to $1 \%$ of its total mass.

Figure 3. Follow-up of clinical and laboratory parameters in FD patient (index case) over the ERT. (A) LVMI decreased between baseline, 12, and 24 months of ERT. (B) There was a decrease of proteinuria between baseline, 12, 24, and 36 months of ERT. (C) An increase in the eGFR between baseline, 24, and 36 months over ERT.

A)

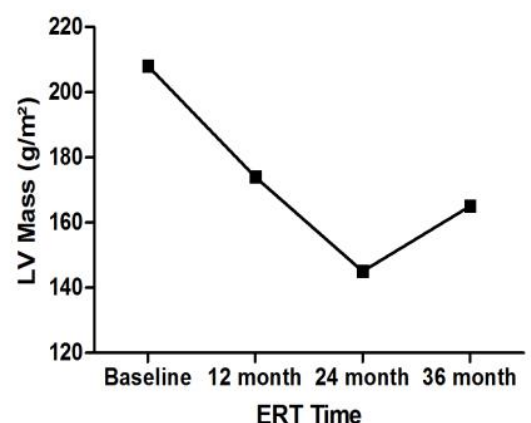

B)

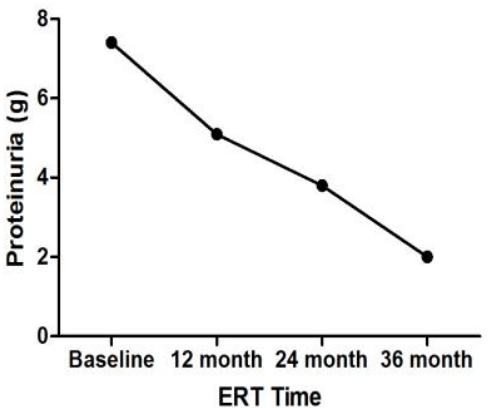

C)

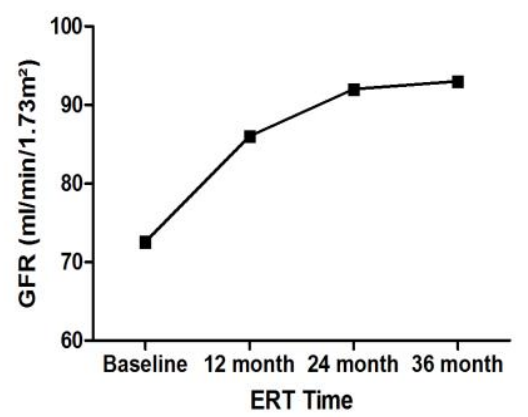

Source: The authors, 2019. 


\section{CASE 02}

The fact that FD is a chromosome X-linked pathology tells us that any daughter of an affected man will necessarily be a carrier of the disease. Thus, with the support of this rationale and based upon the pedigree (Figure 2) attained from the familial screening, we evaluated the daughter (IV-3) of the index case (III-1) as for the clinical history and the presence of the familial mutation in the GLA gene. The exonic sequencing of the GLA gene confirmed the presence of the pathogenic mutation c.1046G $>C$ p.W349S in the exon 7, whose phenotypical effect was ratified by the serum concentration of lyso-Gb3 $(2.2 \mathrm{ng} / \mathrm{mL})$. Together, these findings confirmed FD in the daughter of the index case.

The patient's clinical history also showed that she was a carrier of SLE using azathioprine and hydroxychloroquine. Complementary examinations to diagnose FD identified the presence of cornea verticillata and alterations in the magnetic resonance, such as microgliosis. Kidney evaluation showed GFR of $100 \mathrm{ml} / \mathrm{min} / 1.73 \mathrm{~m}^{2}$, proteinuria of $800 \mathrm{mg} / 24 \mathrm{~h}$, and hematuria in the urinalysis. Kidney biopsy was indicated, and the histologic findings exhibited class $\mathrm{V}$ lupus nephritis. At the EM lipid deposits were observed in the cytoplasm of podocytes and effacement of pedicles (Figure 4). The complementary immunohistochemical study revealed negativity in the GBM for the anti-PLA2 and IgG4 antibodies.

Figure 4. Electron microscopy: Case 2 - Presence of amorphous deposits in the subendothelial and subepithelial spaces - spicules - (white arrows) and lipid deposits in the cytoplasm of podocytes (gray arrows).

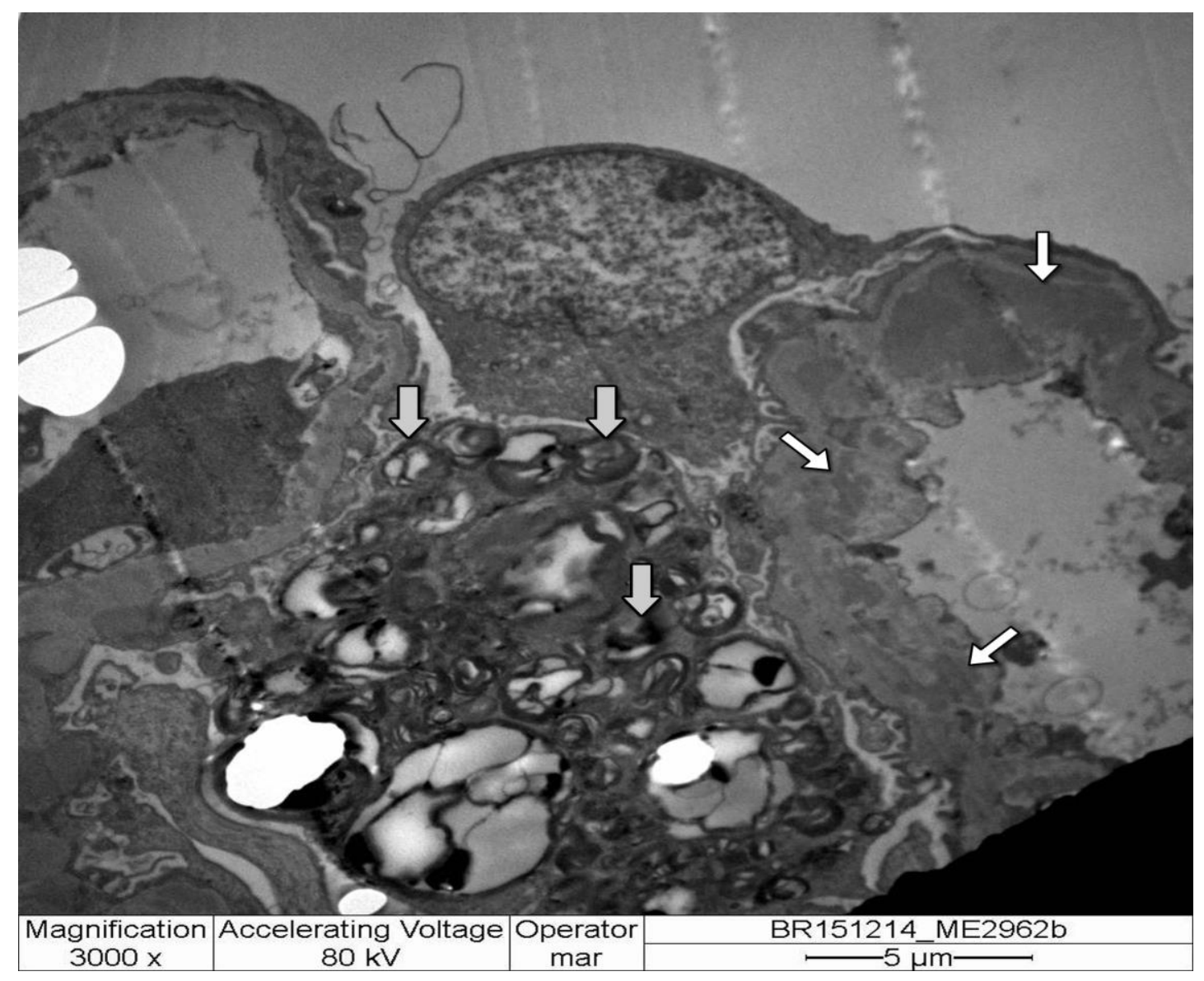

Source: Dr. Marlene Antônia dos Reis, 2019.

The findings confirmed a coexistence of FD and an autoimmune disease, the patient started the ERT with agalsidase alfa, was encouraged to visit a rheumatologist, and to discontinue the use of hydroxychloroquine. 


\section{DISCUSSION}

Here we describe a rare coincidence of two patients with FD in the same family associated, one with primary glomerulonephritis (GN) and the other with secondary GN related to SLE.

The accumulation of the Gb3 substrate in lysosomes and cell cytoplasm is not inert and interferes in the function of different cells, including those of the immune system, causing chronic stimulation of their components (MAUHIN W, et al., 2015).

Several case reports show coexistence of Fabry Disease and glomerular diseases, with IgA Nephropathy (IgAN) being the most frequent (MAIXNEROVÁ D, et al., 2013; WHYBRA C, et al., 2006). Whether FD has an activator role in the IgAN remains unclear. However, it has been shown that the accumulation of glycosphingolipids can induce an autoimmune response (HAMERS MN, et al., 1978), and in an animal, model glomerulonephritis was induced by a structurally similar molecule to Gb3 (SHIBATA, S et al., 1988).

The occurrence of FD with other GN by IC are rare events from whose studies answers may arise for unfathomable essential questions, e.g. (1) Is the molecular mimicry a necessary condition for the coexistence of both pathologies? (2) Is the accumulated Gb3 able to trigger responses from autoantibodies? The answers to these questions are of great relevance as they will provide the basis for managing the factors that potentiate the formation of immune complexes in genetically susceptible individuals.

In Case 1, the patient has a rare association of autoimmune disease and FD. The coloration by immunohistochemistry confirmed the IC against an endogenous antigen to PLA2. Although the tissue coloration has been poor, the level of the serum anti-PLA2 antibody was high, confirming thus the primary GN involving the immunoglobulin IgG4-complexed PLA2 podocyte antigen. Hence, this patient exhibits a double injury to the podocyte: by the chronic and progressive accumulation of Gb3, with later complementdependent cytotoxicity, and by the dysfunction of the PLA2 receptor in the podocyte's membrane.

In recent research, Seitz-Polski B et al. (2016) suggested that the development of primary MN depends on mimicry of microbial and environmental antigens with PLA2 protein. However, the fact of the PLA2 receptor being low-expressive in the podocytes' membrane and, therefore, little access to circulating T-cells, minimize the chances of this being the inducer of the autoimmune response in the cases herein. This leads us to question whether - in FD - Gb3 can be a metabolic trigger for autoimmunity in families susceptible to such diseases, as in FD there is a chronic and increasing accumulation of Gb3 in podocytes to start from the kidney embryogenesis (BRADY RO, et al., 1971).

Actually, the Gb3-impregnated podocytes occur very early, as proved by Najafian B et al. (2011), by publishing that podocytes are the most attacked cells in children, carriers of FD, in the absence of microalbuminuria, and/or alteration of GFR. Tøndel C et al. (2013) observed that the early use of ERT in the population studied could reverse the EP-like histologic damages leading to the clearance of podocyte deposits.

In case 2, there is the association of FD and SLE. Though rare this association, it is believed to be underdocumented, regarding that FD is a rare and less symptomatic disease in women and, therefore, greatly delays diagnosis, which occurs on average in the 3rd or $4^{\text {th }}$ decade of their lives. Contrariwise, SLE is very frequent in women usually in their second decade of life, corroborating our case, whose SLE diagnosis precedes that of Fabry in a decade. The accumulation of Gb3 causes changes in the lymphocyte cell membranes enabling a favorable environment for autoimmune disease. Martinez and collaborators evaluated the prevalence of anti-extractable nuclear antigens in FD patients finding the positivity of at least one antibody in $57 \%$ of patients (MARTINEZ P, et al., 2007).

Although impregnation of podocytes by Gb3 is a characteristic finding of Fabry nephropathy, it is not pathognomonic. Thence, the analysis of histologic findings is necessary for the light of clinical, laboratory, and genetic knowledge for a differential diagnosis. Drug-induced impregnation is dose-dependent and reversible with its interruption, as recently shown by de Menezes Neves PDM et al. (2017). In case 2, the patient had been using chloroquine since the diagnosis of SLE, but she was a mandatory carrier of the

REAS/EJCH | Vol. 11 (12) | e503 | DOI: https://doi.org/10.25248/reas.e503.2019 Página 7 de 9 
mutation, as she is a daughter of the index case. Chloroquines are widely known as inducers of lysosomal enzymes dysfunction, responsible for the degradation of lipid substrates in lysosomes (DONG $\mathrm{H}$ and CZAJA MJ, 2011).

Therefore, the use of chloroquine by FD carriers must be given in-depth consideration, with the risk of potentiating the accumulation of podocyte Gb3, accelerating podocyturia, albuminuria, and loss of kidney function. With this rationale in mind, Case 2 of this study was discussed with a rheumatologist over the risks and benefits of discontinuing the use of adjuvant chloroquine in the treatment of SLE, regarding it as an additional factor for the accumulation of $\mathrm{Gb3}$ in the different cells of the organism.

Lastly, the importance of the kidney biopsy is pointed out in the cases reported here. Systematic histologic examination of kidney biopsy specimens not only confirmed the preliminary diagnosis of membranous nephropathy, but also provided evidence indicative of Fabry nephropathy, leading to identification of Fabry disease in the proband and his family members, allowing early diagnosis and genetic counseling on a hereditary disease with a still late diagnosis with severe complications in organs such as kidney, heart, and the CNS.

\section{ACKNOWLEDGMENTS}

The authors would like to thank Dr. Marlene Antônia dos Reis of the Universidade Federal de Minas Gerais, who kindly provided the biopsies images of this study and Dr. Gianna Mastroianni Kirsztajn of the Universidade Federal de São Paulo for performing the serological tests.

\section{REFERENCES}

1. BRADY RO, et al. Fabry's disease: antenatal detection. Science, 1971; 172(3979):174-175.

2. DE MENEZES NEVES PDM, et al. Ultrastructural deposits appearing as "zebra bodies" in renal biopsy: Fabry disease? - comparative case reports. BMC Nephrology, 2017; 18(1): 157.

3. DESNICK RJ, et al. a-Galactosidase A deficiency: Fabry disease. In: Valle D, et al., editors. The metabolic and molecular bases of inherited disease. 8th ed. New York: McGraw-Hill, 2001. p. 3733-3774.

4. DONG H, CZAJA MJ. Regulation of lipid droplets by autophagy. Trends in Endocrinology and Metabolism, 2011; 22(6): 234-240.

5. HAMERS MN, et al. Characterization of antibodies against ceramidetrihexoside and globoside. Immunochemistry, 1978; 15(6): 353-358.

6. ICHIKAWA I, et al. Podocyte damage damages podocytes: autonomous vicious cycle that drives local spread of glomerular sclerosis. Current Opinion in Nephrology and Hypertension, 2005; 14(3): 205-210.

7. JURY EC, et al. Lipid rafts in T cell signalling and disease. Seminars in Cell and Developmental Biology, 2007; 18(5): 608-615.

8. KRIZ W, et al. The podocyte's response to stress: the enigma of foot process effacement. American Journal of Physiology-Renal Physiology, 2013; 304(4): F333-347.

9. LEMANSKY P, et al. Synthesis and processing of alpha-galactosidase $A$ in human fibroblasts. Evidence for different mutations in Fabry disease. Journal of Biological Chemistry, 1987; 262(5): 2062-2065.

10. LIU Y, et al. Coexistence of Fabry Disease and Membranous Nephropathy. Iranian Journal of Kidney Diseases, 2016; 10(1): 48-50.

11. MAIXNEROVÁ D, et al. The coincidence of IgA nephropathy and Fabry disease. BMC Nephrology, 2013; 14: 6.

12. MARTINEZ P, et al. High incidence of autoantibodies in Fabry disease patients. Journal of Inherited Metabolic Disease, 2007; 30(3): 365-269.

13. MAUHIN W, et al. Innate and Adaptive Immune Response in Fabry Disease. JIMD Reports, 2015; $22: 1$ 1-10.

14. MEHTA A, et al. Fabry disease defined: baseline clinical manifestations of 366 patients in the Fabry Outcome Survey. European Journal of Clinical Investigation, 2004; 34(3): 236-242.

15. MEHTA A, et al. Natural course of Fabry disease: changing pattern of causes of death in FOS - Fabry Outcome Survey. Journal of Medical Genetics, 2009; 46(8): 548-552. 
16. MEHTA A, HUGHES DA. Fabry Disease. In: ADAMS MP, et al., editors. GeneReviews. Washington: University of Washington, 1993-2018. [Updated 2017 Jan 5; cited 2017 Dec 28]. Available from: https://www.ncbi.nlm.nih.gov/books/NBK1292/. Access on: May 22, 2018.

17. NAJAFIAN B, et al. Progressive podocyte injury and globotriaosylceramide (GL-3) accumulation in young patients with Fabry disease. Kidney International, 2011; 79(6): 663-670.

18. PLATT FM, et al. The cell biology of disease: lysosomal storage disorders: the cellular impact of lysosomal dysfunction. Journal of Cell Biology, 2012; 199(5): 723-734.

19. SANCHEZ-NIÑO MD, et al. Globotriaosylsphingosine actions on human glomerular podocytes: implications for Fabry nephropathy. Nephrology Dialysis Transplantation, 2011; 26(6): 1797-1802.

20. SEITZ-POLSKI B, et al. Epitope Spreading of Autoantibody Response to PLA2R Associates with Poor Prognosis in Membranous Nephropathy. Journal of the American Society of Nephrology, 2016; 27(5): 1517-1533.

21. SHIBATA S, et al. The structure of nephritogenoside. A nephritogenic glycopeptide with alpha-N-glycosidic linkage. Journal of Biological Chemistry, 1988; 263(25): 12483-12485.

22. TONDEL $\mathrm{C}$, et al. Renal biopsy findings in children and adolescents with Fabry disease and minimal albuminuria. American Journal of Kidney Diseases, 2008; 51(5): 767-776.

23. TONDEL C, et al. Agalsidase benefits renal histology in young patients with Fabry disease. Journal of the American Society of Nephrology, 2013; 24(1): 137-148.

24. VALBUENA C, et al. Kidney biopsy findings in heterozygous Fabry disease females with early nephropathy. Virchows Archiv, 2008; 453(4): 329-338.

25. WHYBRA C, et al. IgA nephropathy in two adolescent sisters heterozygous for Fabry disease. Pediatric Nephrology, 2006; 21(9): 1251-1256. 